\title{
Una ciudad flexible de extraños ${ }^{1} \quad$ A Flexible City of Strangers ${ }^{1}$
}

\author{
Richard Sennett Profesor, London School of Economics.
}

Las ciudades, aún cuando tienden a perder su encanto en la medida en que se transforman en espacios estandarizados e impersonales, mantienen la capacidad para atraer a las personas. Los individuos están de paso y las empresas no están ancladas a la ciudad ni se hacen responsables de ella. La convivencia se transforma en una suerte de tregua fundada en la indiferencia mutua.

NUEVO CAPITALISMO, NUEVA AISLACIÓN / Antes la gente venía a la ciudad en busca del anonimato, de la diversidad y de la libertad para conocer a otros. Las ciudades también representaban lugares de lucha colectiva y de solidaridad. Actualmente, y justo cuando el lugar de trabajo se ve afectado por un nuevo sistema de trabajo flexible, las ciudades también arriesgan la pérdida de su encanto, así como las empresas y la arquitectura se vuelven cada vez más estandarizadas e impersonales.

Las ciudades pueden estar mal manejadas, propensas al crimen, sucias y decadentes. Sin embargo, mucha gente considera que vale la pena vivir inclusive en la peor de ellas. ¿Por qué? Porque una ciudad tiene el potencial de convertirnos en seres humanos más complejos. La ciudad es un lugar donde las personas pueden aprender a vivir con extraños, a compartir experiencias e intereses de vidas ajenas a las suyas. Lo rutinario aturde la mente mientras que la diversidad la estimula y la expande. La ciudad le permite a la gente desarrollar un sentimiento más rico y más complejo de ellos mismos. Las personas no son únicamente banqueros, o barrenderos municipales, afrocaribeños o anglosajones, de habla inglesa o española, burgueses o proletarios: pueden ser parte de estos o todos estos y más. No están sujetos a un esquema predeterminado de identidad. Las personas pueden desarrollar imágenes múltiples de identidades. Sabiendo quiénes son, pueden cambiar según con quien estén. Este es el poder de lo desconocido: la libertad de una definición e identificación cualquiera.

La escritora Willa Cather vivía atemorizada en un área rural de Estados Unidos por miedo a que se descubriera su condición de lesbiana. Cuando finalmente en 1906 llegó a Greenwich Village en Nueva York, le escribió a una amiga: "finalmente, en este lugar indescifrable, puedo respirar". En público los citadinos pueden usar una máscara impasible, actuar de manera fría e indiferente hacia otros en la calle; sin embargo, en privado pueden ser despertados por esos contactos extraños, y sus certezas sacudidas por la presencia de otros.

Estas virtudes no son inevitables. Uno de los grandes temas de la vida urbana es como conseguir que las complejidades de una gran urbe interactúen para que las personas puedan ser verdaderamente cosmopolitas y cómo convertir las calles atestadas en lugares de auto-conocimiento y no de miedo. El filósofo francés Emmanuel Levinas se ha referido al sentimiento de vecinos entre extraños en una frase que captura la aspiración que debemos de tener en cuenta para diseñar nuestras ciudades.

Arquitectos y planificadores se ven enfrentados a nuevos retos. La globalización ha transformado la producción que ahora permite a las personas trabajar de manera más flexible, menos rígida y que, a la vez, permite experimentar la ciudad de otra manera. En el s. XIX el sociólogo alemán Max Weber comparó las empresas modernas con organizaciones militares. Ambas trabajaban sobre un principio piramidal con el general o jefe en la cumbre y los soldados o trabajadores en su base. La división laboral minimizaba la duplicación y le otorgaba a cada grupo de traba-
Richard Sennett Professor, London School of Economics.

Cities, even though they tend to lose their charm as they become transformed into standardized and impersonal spaces, maintain their ability to attract individuals. Individuals are passing through and companies are not anchored to the city nor do they assume responsibility for it. Cohabitation becomes a sort of truce based on mutual indifference.

New Capitalism, new isolation / Once people used to come to the city in search of anonymity, diversity and the freedom to meet others. Cities were also places of collective struggle and solidarity. Now, just as the workplace is affected by a new system of flexible working, so the city, too, risks losing its charm as businesses and architecture become standardised and impersonal.

Cities can be badly-run, crime-infested, dirty, decaying. Yet many people think it worth living in even the worst of them. Why? Because cities have the potential to make us more complex human beings. A city is a place where people can learn to live with strangers, to enter into the experiences and interests of unfamiliar lives. Sameness stultifies the mind; diversity stimulates and expands it.

The city can allow people to develop a richer, more complex sense of themselves. They are not just bankers or roadsweepers, Afro-Caribbeans or Anglo-Saxons, speakers of English or of Spanish, bourgeois or proletarian: they can be some or all of these things, and more. They are not subject to a fixed scheme of identity. People can develop multiple images of their identities, knowing that who they are shifts, depending upon whom they are with. That is the power of strangeness: freedom from arbitrary definition and identification.

Writer Willa Cather was haunted in small-town America by the fear that her lesbianism would be discovered. When she finally arrived in New York's Greenwich Village in 1906, she wrote to a friend: "At-last, in this indecipherable place, I can breathe". In public, city dwellers may don an impassive mask, act cool and indifferent to others on the street; but in private, they can be aroused by these strange contacts, their certainties shaken by the presence of others.

These virtues are not inevitable. One of the big issues in urban life is how to make the complexities that a city contains interact -so that people become truly cosmopolitan- and how to turn crowded streets into places of self-knowledge, not fear. The French philosopher Emmanuel Levinas has referred to the neighbourliness of strangers, a phrase that captures the aspiration we should have in designing our cities.

Architects and planners are faced with new challenges. Globalisation has transformed production which now allows people to work more flexibly, less rigidly and makes them experience the city differently.

In the $19^{\text {th }}$ century the German sociologist Max Weber compared modern business organisations to military organisations. Both worked on the principle of a pyramid, with the general or boss at the apex and the soldiers or workers at the base. The division of labour minimised duplication and gave each group of workers at the base a distinct function. In this way the corporation executive at the apex could determine how the assembly line or back office functioned, just as the general could strategically command platoons far from his command post. And as the division of labour progressed, the need for different kinds of workers expanded far more rapidly than the need for more bosses. 
jadores en la base una función particular. De esta manera el ejecutivo corporativo en lo alto podía determinar cómo la cadena de montaje u oficina operaba, del mismo modo en que un general podía estratégicamente comandar a secciones militares desde su mando de control. Y a medida que progresaba la división de trabajo, la necesidad de contar con diferentes trabajadores se expandía mucho más rápidamente que la de contar con más jefes.

En la producción industrial, la pirámide de Weber se plasmó en el fordismo, un tipo de micro-manejo militar del tiempo y esfuerzo de un trabajador el cual unos pocos expertos podían dirigir desde arriba. Esto fue gráficamente ilustrado en la planta automotriz de General Motors Willow Run en Estados Unidos, un edificio de un $1.6 \mathrm{~km}$ de largo y 0.4 $\mathrm{km}$ de ancho en el cual hierro crudo y vidrio entraban por un lado y un auto completo salía por el otro. Únicamente un régimen estricto de control laboral podía coordinar la producción a tan gran escala. En el mundo del trabajador profesional, el control por parte de corporaciones como IBM en los años sesenta reflejaba este proceso industrial.

Hace una generación las empresas comenzaron a rebelarse contra la pirámide de Weber. Buscaron remover capas organizacionales, niveles de burocracia (utilizando nuevas tecnologías de información en lugar de burócratas) y cambiar la práctica de trabajo y funciones fijas, sustituyéndolas por equipos que pudiesen trabajar a corto plazo en tareas específicas. En el marco de la nueva estrategia de negocios, los equipos compiten unos contra otros, intentando responder de la manera más efectiva y rápida a las metas impuestas desde arriba. En vez de que cada persona haga su pequeña parte particular en una cadena de comando definida, las funciones se duplican: muchos equipos diferentes compiten por realizar la misma tarea de manera más rápida y mejor. De este modo la corporación puede responder de manera más ágil a los cambios en las demandas del mercado.

Los apólogos del nuevo mundo de trabajo afirman que es más democrático que el estilo militar antiguo de organización. Sin embargo eso no es cierto. La pirámide de Weber ha sido reemplazada por un círculo con un punto en el centro. En el centro un número pequeño de gerentes toman decisiones, establecen metas y juzgan resultados. La revolución informática les ha brindado más control instantáneo sobre el funcionamiento de la corporación que el sistema antiguo, donde las órdenes a menudo eran moduladas y evolucionaban a medida que bajaban por la cadena de mando. Los equipos trabajando en la periferia del círculo se liberan para responder a metas de rendimiento establecidas por el centro y son libres también para formular maneras de ejecutar tareas en competencia una con otra. Sin embargo, no se ven más libres de decidir cuáles serán esas tareas.

En la pirámide weberiana de burocracia, las recompensas se obtenían por hacer el trabajo lo mejor posible. En el círculo de punto, las recompensas se obtienen por equipos que le ganan a otros equipos. El economista Robert Frank le llama la organización que todo gana. Este rediseño burocrático, dice Frank, contribuye hacia las grandes inequidades en el sueldo y en los bonos de las organizaciones flexibles.

No AL LARGo PLAZo / El mantra del lugar de trabajo flexible es no al largo plazo. Las trayectorias profesionales han sido reemplazadas por empleos que consisten en tareas específicas y limitadas, y cuando dicha tarea termina también termina el empleo. En el sector de alta tecnología de Silicon Valley en California, la duración media de empleo es ahora de aproximadamente ocho meses. Las personas constantemente cambian de compañeros de trabajo: la teoría moderna de gestión afirma que la vida útil de un equipo debiera ser de al menos un año.
In industrial production, Weber's pyramid became embodied in Fordism, a kind of military micro-management of a worker's time and effort which a few experts could dictate from the top. It was graphically illustrated by General Motors' Willow Run automobile plant in the United States, a mile-long, quarter-mile wide edifice in which raw iron and glass entered at one end and a finished car emerged at the other. Only a strict, controlling work regime could coordinate production on this giant scale. In the white collar world, the strict control by corporations like IBM in the 1960s mirrored this industrial process.

A generation ago businesses began to revolt against the Weberian pyramid. They sought to de-layer organisations, to remove levels of bureaucracy (using new information technologies in place of bureaucrats) and destroy the practice of fixed-function work, substituting instead teams which work short-term on specific tasks. In this new business strategy, teams compete against one another, trying to respond as effectively and quickly as possible to goals set by the top. Instead of each person doing his or her own particular bit in a defined chain of command, function is duplicated: many different teams compete to do the same task fastest and best. The corporation can thus respond more quickly to changing market demands.

The apologists for the new world of work claim it is also more democratic than the old military-style organisation. But that is not so. The Weberian pyramid has been replaced by a circle with a dot in the centre. At the centre, a small number of managers make decisions, set tasks, judge results; the information revolution has given them more instantaneous control over the corporation's workings than in the old system, where orders often modulated and evolved as they passed down the chain of command. The teams working on the periphery of the circle are left free to respond to output targets set by the centre, free to devise means of executing tasks in competition with one another. But no freer than they ever were to decide what those tasks are.

In the Weberian pyramid of bureaucracy, rewards came for doing your job as best you could. In the dotted circle, rewards come to teams winning over other teams. The economist Robert Frank calls it the winner-take-all organisation; sheer effort no longer produces reward. This bureaucratic reformulation, Frank argues, contributes to the great inequalities of pay and perks in flexible organisations.

No LONG TERM / The mantra of the flexible work-place is no long term. Career paths have been replaced by jobs which consist of specific and limited tasks; when the task ends, the job is often over. In the high-tech sector in Silicon Valley, California, the average length of employment is now about eight months. People constantly change their working associates: modern management theory has it that the shelf life of a team ought to be at most a year.

This pattern does not dominate the work-place at present. Rather, it represents a leading edge of change, what businesses ought to become: no-one is going to start a new organisation based on the principle of permanent jobs. The flexible organisation does not promote loyalty or fraternity any more than it promotes democracy. It is hard to feel committed to a corporation which has no defined character, hard to act loyally to an unstable institution which shows no loyalties to you. Business leaders are now finding that lack of commitment translates into poor productivity and to an unwillingness to keep corporate secrets.

The lack of fraternity that comes from no long term is rather more subtle. Task-work puts people under enormous stress; and recriminations among losing teams mark the final stages of working together. Again, trust of an informal sort takes time to develop; you have to get to 
Este modelo no domina aún el lugar de trabajo. Más bien, representa una punta de lanza de cambio de lo que las empresas debieran ser: nadie comenzará una nueva organización basada en el principio de empleos permanentes. La organización flexible no promueve la lealtad o la fraternidad más de lo que la promueve la democracia. Es difícil sentirse comprometido con una corporación que no tiene un carácter definido. Es difícil actuar de manera leal hacia una institución poco estable que no demuestra lealtad. Líderes empresariales están ahora descubriendo que una falta de compromiso se traduce en una baja de productividad y en una reticencia a guardar secretos corporativos.

La falta de fraternidad que deriva de un no al largo plazo es bastante más sutil. Las labores asignadas en base a productos pone a la gente bajo un estrés incalculable; y las recriminaciones entre equipos perdedores marcan las etapas finales de una labor conjunta. Nuevamente, la confianza en un contexto informal demora en restablecerse. Hay que conocer a la gente. $Y$ la experiencia de estar solo temporalmente en una organización empuja a la gente a mantenerse desconectada y sin involucrarse, bajo el entendido que uno también dejará la empresa a corto plazo.

En efecto, esta falta de compromiso mutuo es una de las razones por las que se vuelve tan difícil para un sindicato organizar a trabajadores de industrias flexibles o empresas de Silicon Valley. El sentido de fraternidad como un destino compartido con una serie de intereses comunes ha sido debilitado. Socialmente, el régimen de corto plazo es paradójico. Las personas trabajan de manera más intensa, bajo gran presión. Sin embargo, sus relaciones hacia los demás se mantienen curiosamente superficiales. Este no es un mundo en el cual deba uno involucrarse de manera profunda con otras personas o donde tenga demasiado sentido el largo plazo.

El capitalismo flexible tiene precisamente el mismo efecto en la ciudad que en el lugar de trabajo, caracterizándose por ser superficial, basado en relaciones de trabajo a corto plazo y en relaciones desapegadas hacia la ciudad. Esto se manifiesta de tres maneras, siendo la más evidente la pertenencia que se produce con la ciudad. Las tasas de movilidad geográfica son muy altas en el caso de trabajadores flexibles. Los empleados temporales representan el sector de mayor crecimiento en el mercado laboral. Enfermeras temporales por ejemplo, son ocho veces más propensas a moverse de casa en un período de dos años que enfermeras empleadas por un único empleador. En los escalones más altos de la economía, los ejecutivos se mudaban con tanta frecuencia en el pasado como en el presente. Sin embargo, estos cambios eran distintos ya que permanecían dentro del perímetro de la empresa y la empresa definía su lugar, o el nicho de sus vidas, sin importar adonde estaban ubicados en el mapa. Es justamente este enlace el que el nuevo lugar de empleo quiebra. Algunos especialistas en estudios urbanos han manifestado que para esta elite el estilo de vida en la ciudad importa más que sus empleos, con algunas zonas de tipo burgués repletas de restaurantes chic y de servicios especializados reemplazando a la empresa como un ancla.

Arquitectura de PIEL / La segunda expresión del nuevo capitalismo se asocia a la estandarización del entorno. Algunos años atrás, en un tour al edificio Chanin de Nueva York, un palacio art déco con oficinas sofisticadas y espléndidas, el jefe de una gran corporación nueva mencionó que "no calzaría con nosotros. La gente podría apegarse demasiado a sus oficinas. Podrían pensar que pertenecen aquí". La oficina flexible no trata de ser un lugar que acoja. La arquitectura de una empresa flexible requiere de un espacio físico el cual pueda ser rápidamente reconfigurado, en su expresión más extrema la oficina puede simplemente ser un terminal know people. And the experience of being only temporarily in an organisation prompts people to keep loose, not to get involved, since you are going to exit soon.

Besides, this lack of mutual engagement is one of the reasons it is so hard for trade unions to organise workers in flexible industries or businesses as in Silicon Valley; the sense of fraternity as a shared fate, a durable set of common interests, has been weakened. Socially, the short-term regime produces a paradox. People work intensely, under great pressure, but their relations to others remain curiously superficial. This is not a world in which getting deeply involved with other people makes much sense in the long run.

Flexible capitalism has precisely the same effects on the city as it does on the workplace itself: superficial, short-term relations at work, superficial and disengaged relations in the city. It appears in three forms. The most self-evident is physical attachment to the city. Rates of geographic mobility are very high for flexible workers. Temps are the single fastestgrowing sector of the labour market. Temporary nurses, for example, are eight times more likely to move house in a two-year period than are single-employer nurses. In the higher reaches of the economy, executives frequently moved as much in the past as they do in the present. But the movements were different in kind; they remained within the groove of a company, and the company defined their place, the turf of their lives, no matter where they were on the map. It is just that thread which the new work-place breaks. Some specialists in urban studies have argued that, for this elite, style of life in the city matters more than their jobs, with certain zones gentrified, filled with sleek restaurants and specialised services replacing the corporation as an anchor.

SKIN ARCHITECTURE / The second expression of the new capitalism is the standardisation of the environment. A few years ago, on a tour of New York's Chanin Building, an art déco palace with elaborate offices and splendid public spaces, the head of a large, new-economy corporation remarked: "It would never suit us. People might become too attached to their offices. They might think they belong here".

The flexible office is not meant to be a place where you nestle in. The office architecture of flexible firms requires a physical environment which can be quickly reconfigured. At the extreme, the office can become just a computer terminal. The neutrality of new buildings also results from their global currency as investment units; for someone in Manila easily to buy or sell 100,000 square feet of office space in London, the space itself needs the uniformity and transparency of money. This is why the style elements of new-economy buildings become what US architectural critic Ada Louise Huxtable calls skin architecture: the surface of the building dolled-up with design, its innards ever more neutral, standard, and capable of instant refiguration.

Alongside skin architecture, we have the standardisation of public consumption, a global network of shops selling the same commodities in the same kinds of spaces whether they are located in Manila, Mexico City or London. It is hard to become attached to a particular Gap or Banana Republic; standardisation breeds indifference. Put it another way. The problem of institutional loyalties in the work-place -now beginning to sober up managers once blindly enthusiastic about endless corporate re-engineering- finds its parallel in the urban public realm of consumption. Attachment and engagement with specific places is dispelled under the aegis of this new regime. Cities cease to offer the strange, the unexpected or the arousing. Equally, the accumulation of shared history, and so of collective memory, diminishes in these neutral public spaces. Standardised consumption attacks local meanings 
de computador. La neutralidad de los nuevos edificios también llega a representar un tipo de moneda local por ser ellos unidades de inversión. En este sentido, alguien en Manila puede fácilmente comprar o vender $30.000 \mathrm{~m}^{2}$ de espacios de oficinas en Londres. El espacio en sí requiere de la misma homogeneidad y transparencia con que cuenta el dinero. Es por ello que los elementos de estilo de los edificios de la nueva economía se convierten en lo que la crítica norteamericana de arquitectura Ada Louise Huxtable denomina arquitectura de piel: donde la superficie de un edificio es diseñada detalladamente, sin embargo sus interiores permanecen neutros, estandarizados y capaces de una transformación instantánea.

De la mano de la arquitectura de piel, se ha dado también la estandarización del consumo público, una red global de tiendas que venden algunas de los mismos productos en espacios similares en Manila, Ciudad de México o Londres. Es difícil sentir apego por una tienda particular de Gap o de Banana Republic y la estandarización produce indiferencia. En otras palabras, el problema de lealtades institucionales en el lugar de trabajo -lo cual ahora comienza a traer mayor sobriedad a gerentes que alguna vez demostraron entusiasmo ciego frente a la re-ingeniería corporativa interminable- encuentra su paralelo en el ámbito público urbano del consumo. El apego y el compromiso hacia lugares específicos son minimizados bajo el alero del nuevo régimen. Las ciudades dejan de ofrecer lo diferente, lo inesperado o lo excitante. De igual manera, una historia compartida en el tiempo, o la memoria colectiva, disminuye en estos espacios públicos neutros. El consumo estandarizado ataca los símbolos locales del mismo modo en que los lugares de trabajo nuevos coartan las historias compartidas y desarrolladas entre colegas.

A simple vista, la tercera expresión de este nuevo capitalismo es menos visible. La alta presión y flexibilidad laboral desorientan de manera muy profunda la vida familiar. Las imágenes familiares en la prensa -niños descuidados, estrés adulto, desarraigo geográfico- no llegan al meollo de esta desorientación. Más bien, son las conductas mismas que determinan el mundo laboral moderno, las que destruirían el núcleo familiar de ser ellas aplicadas desde la oficina a un entorno familiar: el lema sería no se comprometa, no se involucre, piense a corto plazo. La aseveración de valores familiares por parte del público y de los políticos representa más que una resonancia con la derecha; refleja una reacción, algunas veces incoherente pero muy sentida hacia las amenazas a la solidaridad familiar en la nueva economía. El prominente crítico social norteamericano Christopher Lasch dibujó la imagen de una familia como un refugio en un mundo inhumano. Esta imagen toma particular urgencia cuando el trabajo se vuelve a la vez más impredecible y más exigente en el tiempo de los adultos. Un resultado de este conflicto, el cual está ahora bien documentado en relación a los empleados de mediana edad, es que los adultos se retiran de la participación cívica en la lucha por solidificar y organizar su vida familiar; lo cívico se convierte en una demanda más sobre el tiempo y las energías escasas en el hogar.

Los AMADOS PASIVOS / Los efectos de la globalización en las ciudades pueden asociarse a la nueva elite global. Ellos operan en ciudades como Nueva York, Londres y Chicago evitando el ámbito político urbano. Desean operar en la ciudad pero sin dirigirla, abarcando un régimen de poder sin responsabilidad. En Chicago en 1925, por ejemplo, el poder político y el poder económico iban de la mano. Los presidentes de las 80 corporaciones líderes participaron en los consejos directivos de 142 hospitales, abarcando el 70\% de los miembros de los consejos directivos de universidades e institutos. La recaudación de impuestos de 18 corporaciones nacionales en Chicago representó el $23 \%$ del presupuesto municipal de in the same way the new work-place attacks ingrown, shared histories among workers.

The third expression of the new capitalism is less visible to the eye. High-pressure, flexible work profoundly disorients family life. The familiar press images -neglected children, adult stress, geographic uprooting- do not quite get to the heart of this disorientation. It is rather that the codes of conduct which rule the modern work world would shatter families if taken home from the office: don't commit, don't get involved, think short-term. The assertion of family values by the public and politicians has a more than right-wing resonance; it is a reaction, often inchoate but strongly felt, of the threats to family solidarity in the new economy. The prominent American social critic Christopher Lasch drew the image of the family as a haven in a heartless world. That image takes on a particular urgency when work becomes at once more unpredictable and more demanding of adult time. One result of this conflict, by now well-documented in regard to middle-aged employees, is that adults withdraw from civic participation in the struggle to solidify and organise family life; the civic becomes yet another demand on time and energies in short supply at home.

THE PASSIVE BELOVED / That leads to one of the effects of globalisation on cities. The new global elite, operating in cities like New York, London and Chicago, avoids the urban political realm. It wants to operate in the city but not rule it; it composes a regime of power without responsibility.

In Chicago in 1925, for example, political and economic power went hand in hand. Presidents of the city's top 80 corporations sat on 142 hospital boards, accounted for $70 \%$ of the trustees of colleges and universities. Tax revenues from 18 national corporations in Chicago formed 23\% of the city's municipal budget. By contrast, in New York now, few chief executives of global firms are trustees of its educational institutions and none sit on the boards of its hospitals. And it has been well documented how footloose multinational companies like Rupert Murdoch's News Corp manage largely to avoid paying taxes, local or national.

The reason for this change is that the global economy is not rooted in the city in the sense of depending on control of the city as a whole. It is instead an island economy, literally so within the island of Manhattan in New York, architecturally so in places like Canary Wharf in London, which resemble the imperial compounds of an earlier era. As sociologists John Mollenkopf and Manuel Castells have shown, this global wealth does not trickle down or spread out very far beyond the global enclave.

Indeed, the politics of the global enclave cultivates a kind of indifference to the city which Marcel Proust, in an entirely different context, called the passive beloved phenomenon. Threatening to leave, go anywhere in the world, the global firm is given enormous tax breaks to stay a profitable seduction made possible by the firm appearing indifferent to the places where it touches down. In other words globalisation poses a problem of citizenship in cities as well as nations. Cities can't tap into the wealth of these corporations, and the corporations take little responsibility for their own presence in the city. The threat of absence, of leaving, makes possible this avoidance of responsibility; and we lack the political mechanisms to make unstable, flexible institutions contribute fairly for the privileges they enjoy in the city.

All this has an impact on urban civil society which rests on a compromise based on mutual dissociation. That means the truce of leaving one another alone, the peace of mutual indifference. This is one reason why, on the positive side, the modern city is like an accordion easily able to expand to accommodate new waves of migrants, the pockets of difference are sealed. On the negative side, mutual accommodation through 
la ciudad. En contraste, actualmente en Nueva York, pocos ejecutivos líderes de corporaciones globales son miembros de los consejos directivos de instituciones educacionales y ninguno participa de consejos en los hospitales. Asimismo, ha sido bien documentada la manera en que diversas empresas multinacionales, como es la News Corporation de Rupert Murdoch, generalmente realizan las gestiones necesarias para evitar el pago de impuestos locales o nacionales.

La razón por la cual se da un cambio de esta índole se debe a que la economía global no está anclada a la ciudad en el sentido de depender del control de ella como un todo. Más bien, representa una economía aislada; literalmente aislada por su ubicación en la isla de Manhattan en Nueva York o arquitectónicamente en lugares como Canary Wharf en Londres, que se asemejan a condominios imperiales de una era más temprana. Como han demostrado los sociólogos John Mollenkopf y Manuel Castells, esta riqueza global no se escurre o distribuye muy fácilmente o más allá del enclave global. En efecto, la política del enclave global cultiva un cierto tipo de indiferencia hacia la ciudad de la cual Marcel Proust en un contexto enteramente diferente llama el fenómeno de los amados pasivos. Con amenazas de largarse e irse a cualquier parte del mundo, a la empresa global se le brindan enormes deducciones sobre los impuestos por permanecer en un lugar. Estas se asemejan a una seducción rentable la cual se hace posible gracias a la indiferencia reflejada por la empresa hacia su ubicación física. En otras palabras, la globalización posee un problema de ciudadanía tanto en ciudades como en naciones. Las ciudades no pueden acceder a la riqueza de estas corporaciones, y las corporaciones asumen muy poca responsabilidad por su propia presencia en la ciudad. La amenaza de ausencia o de partida hace posible esta falta de responsabilidad. Carecemos de los mecanismos políticos para asegurar que instituciones flexibles e inestables contribuyan de manera razonable a los privilegios que gozan en la ciudad.

Todo esto conlleva un impacto sobre la sociedad civil urbana fundado en un compromiso que a su vez se basa en la disociación mutua. Esto se traduce en una tregua por dejar al otro tranquilo y crear una paz fundada en la indiferencia mutua. Por el lado positivo, esto explica el por qué la ciudad moderna es como un acordeón el cual puede fácilmente agrandarse y acomodar a las nuevas olas de inmigrantes, los bolsillos de la diferencia se sellan. Por el lado negativo, el acomodo mutuo de esta disociación deletrea el fin de las prácticas de la ciudadanía, esto significa una comprensión de intereses divergentes así como también una pérdida de la simple curiosidad humana frente a otra gente.

Asimismo, la flexibilidad del lugar de trabajo moderno crea un sentimiento asociado a lo incompleto. El tiempo flexible se da en serie, es decir, se hace un proyecto y luego otro sin relación al primero, en vez de ser acumulativo. Sin embargo, esto no tiene sentido porque algo falta en la propia vida de la persona. Uno debe volcarse hacia los demás, hacia el sentimiento de vecino de un extraño.

Actualmente, esto sugiere una asociación con el arte de crear mejores ciudades. Necesitamos sobreponer diferentes actividades al mismo espacio, del mismo modo en que alguna vez la vida familiar se sobrepuso al espacio laboral. Lo incompleto del tiempo capitalista nos regresa al tema que marcó la emergencia de la ciudad industrial en una primera instancia. Una ciudad que quebró con el domus, esa relación espacial que antes de la venida del capitalismo industrial combinaba familia, trabajo y espacios ceremoniales públicos con espacios sociales más informales. Hoy necesitamos reparar la colectividad del espacio para combatir el tiempo en serie de la labor moderna. ARQ dissociation spells the end of citizenship practices, which mean understanding divergent interests as well as a loss of simple human curiosity about other people.

At the same time, the flexibility of the modern workplace creates a sense of incompleteness. Flexible time is serial, you do one project, then another unrelated one rather than cumulative. But there is no sense that, because something is missing in your own life, you should turn outward to others, toward that neighbourliness of strangers.

That suggests something about the art of making better cities today. We need to overlay different activities in the same space, as family activity once overlay working space. The incompleteness of capitalist time returns us to the issue which marked the very emergence of the industrial city. A city which broke apart the domus that spatial relation which had, before the coming of industrial capitalism, combined family, work, ceremonial public spaces and more informal social spaces. Today, we need to repair the collectivity of space to combat the serial time of modern labour. ARQ 